Formatif: Jurnal Ilmiah Pendidikan MIPA

Vol. 9, No. 3, September 2019, pp. 203-218

p-ISSN: 2088-351X

e-ISSN: 2502-5457

DOI: http://dx.doi.org/10.30998/formatif.v9i3.3248

\title{
The Transition of Pre-service Chemistry Teachers' Concept Mastery about Solutions in Multiple Representations-Based Learning
}

\author{
Transisi Penguasaan Konsep Calon Guru Kimia tentang Larutan pada \\ Pembelajaran Berbasis Multipel Representasi
}

\author{
Muhamad Imaduddin (*) \\ Institut Agama Islam Negeri Kudus, Jl. Conge Ngembalrejo, Bae, Kabupaten Kudus \\ Kotak Pos 51, Jawa Tengah \\ Sri Haryani \\ Universitas Negeri Semarang, Kampus Unnes Gedung D4, Gunungpati, Sekaran, \\ Gunungpati, Kota Semarang, Jawa Tengah 50229
}

Received: January 25, 2019

Revised: April 20, 2019

Accepted: August 12, 2019

\begin{abstract}
The purpose is to analyze the transition ofpre-service chemistry teachers' concept mastery about solutions in multiple representations-based learning. This research was set through pre-experimental design which is one-group pretest-posttest design. Multiple representations-based learning was applied to Basic Chemistry II course involving 31 first-year preservice chemistry teachers. The instrumentswere a self-assessment sheet on the ability to connect multiple levels of representation (PD-MLP) and the concept mastery tests about solutions (TPKL). Self-assessment and concept mastery was measured based on the scores of the pre-test and post-test and analyzed through normalized gain calculations. Mastery of the concept consists of five mastery indicators. The gain of the concept mastery is at a moderate level (0.30) entirely. Mastery of concept I and IV are much lower than the mastery of other concepts. The shifting groups from TMK category (Not Mastering the Concept) to MSKK (Mastering a Small Part of the Concept) are the most group of pre-service teachers. There is a pre-service teacher who has changed the category from TMK to MK (Mastering the Concept). This pattern can be understood by reviewing the process of concept formation and memory workspace. The instructional content is able to reduce the barrier of feeling difficult. This can be seen from the results of the teachers' self-assessment of their ability to connect the level of chemical representationsleading in a positive direction. This indicates that conceptual understanding increases. The transition ofpre-service chemistry teachers' concept mastery is heading towards a better direction after experiencing multiple representations based-learning.
\end{abstract}

Keywords: Concept mastery, Pre-service chemistry teachers, Multiple representations, Solutions, Concept formation.

(*) Corresponding Author: $\quad$ imad@iainkudus.ac.id \& 085747908045.

How to Cite: Imaduddin, M. \& Haryani, S. (2019). The transition of pre-service chemistry teachers' concept mastery about solutions in multiple representations-based learning. Formatif: Jurnal Ilmiah Pendidikan MIPA, 9 (3): 203-218. http://dx.doi.org/10.30998/formatif.v9i3.3248 
Formatif: Jurnal Ilmiah Pendidikan MIPA

Vol. 9, No. 3, September 2019, pp. 203-218

p-ISSN: 2088-351X

e-ISSN: 2502-5457

DOI: http://dx.doi.org/10.30998/formatif.v9i3.3248

\section{PENDAHULUAN}

Berbagai penelitian telah mengkaji tentang bagaimana peserta didik dalam menguasai konsep-konsep kimia. Penguasaan kimia ditandai dengan kemampuan peserta didik untuk mentransfer dan menghubungkan level makroskopik, submikrokopik, dan simbolik (Farida, 2012; Hinton \& Nakhleh, 1999; A.H. Johnstone, 2000; Alex H. Johnstone, 2000; Talanquer, 2011; Treagust \& Chandrasegaran, 2009; Tuysuz, Ekiz, Uzuntiryaki, Tarkin, \& Kutucu, 2011). Level makroskopik mewakili penggambaran pada fenomena-fenomena nyata yang dapat diamati di kehidupan sehari-hari. Sebagai contoh, pengamatan peserta didik pada perubahan sifat dan materi yang ditandai dengan munculnya gelembung gas, perubahan warna, ataupun proses pengendapan pada reaksi kimia. Materi yang diamati tersebut dideskripsikan sebagai susunan atom-atom, molekulmolekul, maupun ion-ion. Pendeskripsian tersebut merepresentasikan level submikroskopik (atau molekuler) yang memberikan penjelasan atas level partikulat untuk menggambarkan pergerakan-pergerakan elektron, molekul, partikel, dan atom. Adapun kimia selanjutnya dibahasakan melalui representasi simbolik dengan menggunakan simbol-simbol kimia, rumus dan persamaan, gambar struktur molekul, diagram, representasi piktorial, aljabar, maupun bentuk-bentuk komputasional dari representasi submikroskopik (Chandrasegaran, Treagust, \& Mocerino, 2007; Chittleborough \& Treagust, 2007; I. Devetak, Urbančič, K.S.W., Krnel, \& Glažar, 2004; Iztok Devetak, Vogrinc, \& Glažar, 2009; Tasker \& Dalton, 2006; Wu, Krajcik, \& Soloway, 2001).

Program pelatihan calon guru kimia dituntut untuk dapat memberikan penguasaan kimia yang tidak sebatas pada hafalan dan perhitungan matematis saja. Hal tersebut mengarah pada tuntutan perubahan paradigma yang sering terjadi di lapangan bahwa penguasaan kimia lebih banyak ditinjau pada penguasaan perhitungan matematis. Cakupan konsep berkenaan dengan komponen larutan, konsentrasi, serta sifat asam basa pada larutan berair sering diajarkan hanya sebagai hafalan dan perhitungan matematis, tanpa memperhatikan aspek submikroskopik pada jenjang sekolah (Farida, 2012; Imaduddin, 2018; Muchtar, Z. \& Harizal, 2012). Penguasaan konsep pada ketiga level representasi kimia akan bermanfaat bagi calon guru kimia dalam mengomunikasikan kimia kepada peserta didik di masa mendatang (Imaduddin, 2018). Pada jenjang sebelumnya, para calon guru sering belajar bagaimana untuk memecahkan masalah matematika tanpa memahami kimia secara menyeluruh pada ketiga level representasi kimia. Hal ini mengarah pada munculnya miskonsepsi konten kimia (Imaduddin, 2018; Schmidt \& Chemie, 1995). Dengan demikian, pembelajaran kimia yang berbasis multipel representasi yang merujuk pada ketiga level representasi kimia perlu dipersiapkan sebaikbaiknya untuk memperbaiki kondisi miskonsepsi calon guru.

Penelitian ini mengkaji bagaimana transisi atau pergeseran penguasaan konsep tentang larutan pada pembelajaran berbasis multipel representasi. Proses transisi ditinjau dari pergeseran kategori penguasaan konsep calon guru kimia serta signifikansi perbedaan sebelum dan setelah adanya pembelajaran. Penelitian ini mendiskusikan lebih detail proses perubahan penguasaan konsep pada masing-masing indikator penguasaan konsep yang diungkap melalui tes dan penilaian diri calon guru kimia.

\section{METODE}

Penelitian ini berupa pre-experimental design jenis One-Group Pretest-Posttest Design (Cohen, Manion, \& Morrison, 2007). Pembelajaran berbasis multipel representasi diterapkan pada perkuliahan Kimia Dasar II. Pelaksanaan pembelajaran berbantuan media 
Formatif: Jurnal Ilmiah Pendidikan MIPA

Vol. 9, No. 3, September 2019, pp. 203-218

p-ISSN: 2088-351X

e-ISSN: 2502-5457

DOI: http://dx.doi.org/10.30998/formatif.v9i3.3248

audiovisual serta media cetak berupa lembar kerja khusus yang masing-masing memberikan penekanan pada ketiga level representasi kimia. Penelitian ini melibatkan 31 calon guru kimia yang merupakan mahasiswa tahun pertama di salah satu universitas yang ada di Jawa Tengah.

Instrumen pengumpulan data terdiri dari penilaian diri terhadap kemampuan menghubungkan multipel level representasi (PD-MLP) dan tes penguasaan konsep larutan (TPKL) yang masing-masing diberikan kepada calon guru sebelum dan sesudah pembelajaran. PD-MLP terdiri dari tujuh item pernyataan yang diminta untuk ditanggapi oleh calon guru kimia. Skor tanggapan mencakup 1, 2, 3, dan 4 untuk menunjukkan level "sangat negatif" hingga "sangat positif". Hasil total skor yang diperoleh dari tanggapan calon guru selanjutnya ditentukan skor rata-rata per itemnya untuk selanjutnya dikategorikan sebagaimana ditunjukkan pada Tabel 1.

Tabel 1. Kategori Penilaian Diri

\begin{tabular}{cc}
\hline Rentang Kategori Skor & Kategori \\
\hline $4 \geq \overline{\boldsymbol{X}} \geq 3,25$ & Sangat Positif \\
$3,25>\overline{\boldsymbol{X}} \geq 2,5$ & Positif \\
$2,5>\overline{\boldsymbol{X}} \geq 1,75$ & Negatif \\
$1,75>\overline{\boldsymbol{X}} \geq 1$ & Sangat Negatif \\
\hline Keterangan: & \\
$\bar{X} \quad=$ rata-rata skor penilaian aspek tiap item
\end{tabular}

TPKL merupakan tipe criterion-referenced test, yang populer dengan sebutan Penilaian Acuan Patokan (PAP) atau penilaian acuan kriteria. PAP merupakan tes yang digunakan untuk mengukur penguasaan atau kemampuan peserta didik melalui kriteria tertentu yang telah ditetapkan sebelumnya oleh evaluator, tanpa membandingkan dengan penguasaan atau kemampuan siswa lainnya (Sukardi, 2009). Sebelum digunakan untuk kegiatan pengumpulan data, instrumen pengumpulan data diuji validitas dan reliabilitasnya. Pengujian kuantitatif dilakukan dengan teknik uji coba soal pada kelompok tertentu $(\mathrm{N}=22)$. Selanjutnya, dilakukan pengujian reliabilitas, validitas butir, tingkat kesukaran dan daya beda menggunakan aplikasi ANATES Uraian versi 4.0.5 yang dikembangkan oleh Karnoto \& Wibisono (2004). Reliabilitas yang diperoleh sebesar 0,89 . Berdasarkan hasil analisis secara kuantitatif dan kualitatif diperoleh 30 item soal yang tersebar pada lima bagian soal sebagaimana ditunjukkan pada Tabel 2.

Tabel 2. Sebaran Item Soal pada TPKL

\begin{tabular}{lcc}
\hline Bagian Soal & Jumlah Item Soal & Skor Maksimal \\
\hline Bagian I & 4 & 20 \\
Bagian II & 7 & 35 \\
Bagian III & 6 & 30 \\
Bagian IV & 9 & 45 \\
Bagian V & 5 & 20
\end{tabular}

Penafsiran skor TPKL mengacu kriteria yang dimodifikasi dari Abraham, Gtzybowski, Renner, \& Marek (1992) sebagaimana ditunjukkan pada Tabel 3. Calon guru kimia dikategorikan menjadi empat kelompok yaitu MK, MSBK, MSKK, dan TMK. Adapun respons penguasaan konsep pada masing-masing butir soal dibedakan menjadi MK, MS, MM, MIS, MTJ, TM dan TR. Perubahan kategori dan kode pada masingmasing butir soal diidentifikasi lebih lanjut didasarkan pada hasil pre-test dan post-test TPKL calon guru kimia. Perubahan tersebut menunjukkan transisi penguasaan konsep calon guru kimia. 
Formatif: Jurnal Ilmiah Pendidikan MIPA

Vol. 9, No. 3, September 2019, pp. 203-218

p-ISSN: 2088-351X

e-ISSN: 2502-5457

DOI: http://dx.doi.org/10.30998/formatif.v9i3.3248

Tabel 3. Kategorisasi Penguasaan Konsep Calon Guru Kimia

\begin{tabular}{llcc} 
Kode & \multicolumn{1}{c}{ Derajat Pemahaman } & $\begin{array}{c}\text { Kategori Penguasaan } \\
\text { Konsep }\end{array}$ & $\begin{array}{c}\text { Skor atau Rerata } \\
\text { Skor }\end{array}$ \\
\hline MK & Memahami konsep & Menguasai Konsep (MK) & 5 \\
MS & Memahami sebagian & & 4 \\
MM & Memahami sebagian dengan & Mengusai Sebagian Besar & 3 \\
& miskonsepsi & Konsep (MSBK) & 2 \\
MIS & Miskonsepsi & & \\
MTJ & Memahami sebagian tetapi tidak bisa & Kongusai Sebagian Kecil & 1 \\
& memberikan penjelasan & & 0 \\
TM & Tidak memahami & Tidak Menguasai Konsep & \\
TR & Tidak ada respons & (TMK) & \\
\hline
\end{tabular}

Peningkatan penilaian diri dan penguasaan konsep diukur berdasarkan skor pretest dan post-test. Skor total pre-test dan post-test dianalisis melalui perhitungan gain ternormalisasi. Uji ini digunakan untuk menganalisis kriteria pencapaian sebelum dan sesudah pembelajaran (Hake, 1998). Dengan kriteria tingkat capaian $\mathrm{N}$-Gainyaitu $0,00 \leq$ $\langle\mathrm{g}\rangle\langle 0,30=$ rendah; $0,30 \leq\langle\mathrm{g}\rangle\langle 0,70=$ sedang; dan $0,70 \leq\langle\mathrm{g}\rangle\langle 1,00=$ tinggi. Skor total diuji normalitasnya dengan uji Kolmogorov-Smirnov menggunakan aplikasi SPSS. Jika data berdistribusi normal, signifikansi perbedaan sebelum dan sesudah pembelajaran diuji dengan Paired samples t-test. Jika data tidak berdistribusi normal, diuji dengan Wilcoxon signed ranks test (Cohen et al., 2007).

\section{HASIL DAN PEMBAHASAN}

\section{Hasil}

Calon guru diminta untuk menilai dirinya sendiri sebelum dan setelah pembelajaran dilaksanakan. Meskipun hal ini bukan sebagai acuan peningkatan penguasaan konsep, hasil penilaian diri ini dapat digunakan sebagai rujukan terhadap kondisi mental atau persepsi calon guru terhadap dirinya. Hasil analisis penilaian diri calon guru ditunjukkan pada Tabel 4.

Tabel 4. Analisis Penilaian Diri Calon Guru terhadap Kemampuan Menghubungkan Level Representasi Kimia

\begin{tabular}{|c|c|c|c|c|c|c|c|c|}
\hline \multirow{2}{*}{$\begin{array}{c}\text { Skor Penilaian } \\
\text { Diri }\end{array}$} & \multirow{2}{*}{$\begin{array}{c}\text { Rata- } \\
\text { rata } \\
\text { Skor }\end{array}$} & \multirow{2}{*}{$\begin{array}{l}\text { Rata- } \\
\text { rata } \\
\text { Skor/I } \\
\text { tem }\end{array}$} & \multirow[t]{2}{*}{ Kate-gori } & \multirow[t]{2}{*}{$\langle\mathrm{g}\rangle$} & \multirow{2}{*}{$\begin{array}{c}\text { Uji } \\
\text { Signifikansi } \\
\text { Perbedaan* }\end{array}$} & \multicolumn{3}{|c|}{$\operatorname{Rank}^{* *}(\mathrm{~N}=36)$} \\
\hline & & & & & & Negative & Positive & Ties \\
\hline $\begin{array}{c}\text { Sebelum } \\
\text { Pembelajaran }\end{array}$ & 22,7 & 2,5 & Positif & $\begin{array}{c}(0,16) \\
\text { Rendah }\end{array}$ & $\begin{array}{c}\text { Berbeda } \\
\text { signifikan }\end{array}$ & 6 & 25 & 5 \\
\hline $\begin{array}{c}\text { Setelah } \\
\text { Pembelajaran }\end{array}$ & 23,4 & 2,8 & Positif & & & & & \\
\hline $\begin{array}{lr}\text { Keterang } \\
* \quad=1 \\
* * \quad=\mathrm{j} \\
\\
\mathrm{N} \quad=\mathrm{j}\end{array}$ & $\begin{array}{l}\text { : } \\
\text { gujian } \\
\text { lah pes } \\
\text { coxon } S \\
\text { lah pes } \\
\text { abelajar }\end{array}$ & $\begin{array}{l}\text { ngguna } \\
\text { ta didik } \\
\text { ned Ran } \\
\text { ta didik } \\
\text {. }\end{array}$ & $\begin{array}{l}\text { Wilcoxon } \\
\text { Test } \\
\text { ing member }\end{array}$ & $\begin{array}{l}\text { igned } R a t \\
\text { ii perubal } \\
\text { an penila }\end{array}$ & $\begin{array}{l}\text { Test } \\
\text { skor ditunjuk } \\
\text { diri sebelum }\end{array}$ & $\begin{array}{l}\text { pada uji } \\
\text { setelah }\end{array}$ & & \\
\hline
\end{tabular}


Formatif: Jurnal Ilmiah Pendidikan MIPA

Vol. 9, No. 3, September 2019, pp. 203-218

p-ISSN: 2088-351X

e-ISSN: 2502-5457

DOI: http://dx.doi.org/10.30998/formatif.v9i3.3248

Berdasarkan Tabel 4, dapat diketahui bahwa terjadi perbedaan signifikan penilaian calon guru terhadap kemampuannya untuk menghubungkan level representasi kimia. Meskipun demikian, gain atau peningkatan yang terjadi pada level rendah. Selain itu, ada kecenderungan untuk perubahan skor ke arah yang lebih baik ( 25 calon guru) meskipun terdapat enam calon guru kimia yang mengalami penurunan skor. Untuk perubahan kategori penilaian diri, secara rinci dapat dilihat dari Gambar 1.

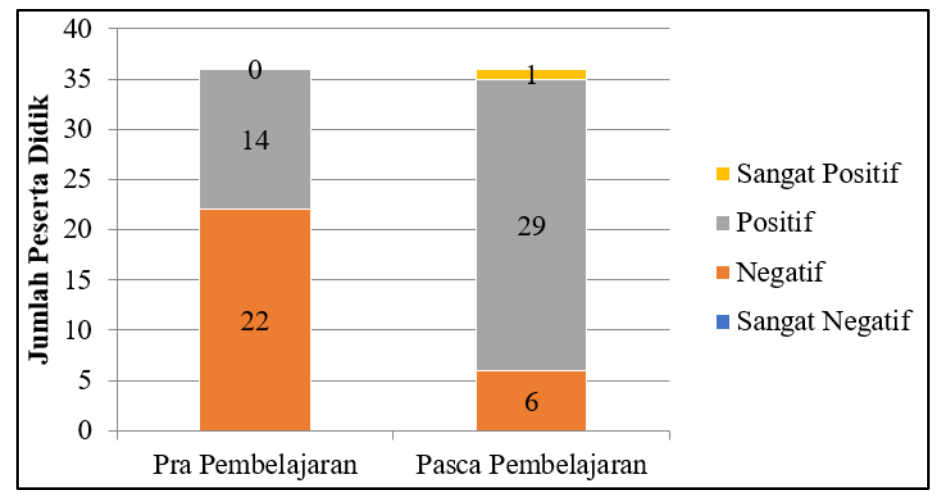

Gambar 1. Profil Penilaian Diri Calon Guru terhadap Kemampuan Menghubungkan Level Representasi Kimia

Berdasarkan Gambar 1, dapat diketahui bahwa terdapat perubahan kategori ke arah yang lebih baik. Jumlah respons "negatif" terhadap diri sendiri menjadi lebih sedikit, sedangkan respons "positif" semakin banyak, serta muncul respons "sangat positif". Hal ini menunjukkan secara mental pembelajaran berbasis mulipel level representasi mampu mengubah persepsi terhadap kemampuan diri peserta didik.

Untuk mengetahui peningkatan penguasaan konsep secara kognitif, dapat dilihat dari hasil tes penguasaan konsep yang diujikan. Data deskriptif dan pengujian sebaran data yang diperoleh dapat dilihat pada Tabel 5.

Tabel 5. Data Deskriptif Penguasaan Konsep

\begin{tabular}{|c|c|c|c|c|c|}
\hline & $\begin{array}{l}\text { Skor Total } \\
\text { Ideal }\end{array}$ & $\begin{array}{c}\text { Skor } \\
\text { Minimum }\end{array}$ & $\begin{array}{c}\text { Skor } \\
\text { Maksimum }\end{array}$ & $\begin{array}{c}\text { Rata-rata } \\
\text { Skor }\end{array}$ & Distribusi Data* \\
\hline $\begin{array}{l}\text { Pre-Test } \\
\text { Post-Test }\end{array}$ & 150 & $\begin{array}{l}18 \\
34\end{array}$ & $\begin{array}{c}78 \\
136\end{array}$ & $\begin{array}{l}41,61 \\
74,65\end{array}$ & $\begin{array}{l}\text { Normal } \\
\text { Normal }\end{array}$ \\
\hline
\end{tabular}

$*$ = pengujian data menggunakan uji Kolmogorov-Smirnov

Tabel 5 menunjukkan bahwa skor maksimum yang ada pada post-test jauh lebih tinggi dari pada skor maksimum pada pre-test. Begitu pula yang terjadi pada skor ratarata yang diperoleh. Hasil analisis data peningkatan penguasaan konsep seperti diuraikan pada Tabel 6. Ditunjukkan bahwa terdapat perbedaan yang signifikan pada penguasaan konsep secara keseluruhan maupun pada masing-masing indikator penguasaan konsep. Secara keseluruhan konsep, dapat diketahui bahwa gain yang diperoleh pada level sedang $(0,30)$. Namun, untuk masing-masing indikator dapat diketahui bahwa PK I dan PK IV memiliki gain pada level rendah $(0,28 \& 0,19)$. Gain rendah yang diperoleh pada PK I dan PK IV menunjukkan secara umum untuk perubahan penguasaan konsep I dan penguasaan konsep IV lebih sedikit dibandingkan konsep-konsep yang lain. 
Formatif: Jurnal Ilmiah Pendidikan MIPA

Vol. 9, No. 3, September 2019, pp. 203-218

p-ISSN: 2088-351X

e-ISSN: $2502-5457$

DOI: http://dx.doi.org/10.30998/formatif.v9i3.3248

Tabel 6. Rekapitulasi Analisis Hasil Pengujian Penguasaan Konsep

\begin{tabular}{lccccc}
\hline \multirow{2}{*}{$\begin{array}{c}\text { Kelompok } \\
\text { Indikator }\end{array}$} & $\langle\mathrm{g}\rangle$ & Uji Signifikansi & \multicolumn{3}{c}{ Rank** } \\
\cline { 4 - 6 } & & Perbedaan* & Negative & Positive & Ties \\
\hline PK & 0,30 (sedang) & Berbeda Signifikan & 1 & 29 & 1 \\
PK I & 0,28 (rendah) & Berbeda Signifikan & 3 & 24 & 4 \\
PK II & 0,35 (sedang) & Berbeda Signifikan & 2 & 28 & 1 \\
PK III & 0,35 (sedang) & Berbeda Signifikan & 3 & 27 & 1 \\
PK IV & 0,19 (rendah) & Berbeda Signifikan & 6 & 22 & 3 \\
PK V & 0,31 (sedang) & Berbeda Signifikan & 1 & 29 & 1 \\
\hline
\end{tabular}

Keterangan:

* $\quad=$ pengujian menggunakan Wilcoxon Signed Ranks Test

** $\quad=$ Jumlah peserta didik yang mengalami perubahan skor dan ditunjukkan pada uji Wilcoxon Signed Ranks Test

$\mathrm{PK} \quad=$ Indikator penguasaan konsep secara keseluruhan

PK I = Membandingkan teori asam-basa menurut teori Arrhenius, Bronsted- Lowry, dan Lewis pada level makroskopik, submikroskopik, dan simbolik.

PK II = Menunjukkan hubungan konsep kesetimbangan dalam larutan asam basa dan penentuan $\mathrm{pH}$ larutan pada level makroskopik, submikroskopik, dan simbolik.

PK III = Menunjukkan hubungan konsep larutan penyangga dan penentuan $\mathrm{pH}$ larutan pada level makroskopik, submikroskopik, dan simbolik.

$\mathrm{PK} I V=$ Menunjukkan hubungan konsep hidrolisis dalam larutan dan penentuan $\mathrm{pH}$ larutan pada level makroskopik, submikroskopik, dan simbolik.

$\mathrm{PK} \mathrm{V}=$ Menunjukkan hubungan konsep kelarutan dan hasil kali kelarutan, serta efek dari penambahan ion pada level makroskopik, submikroskopik, dan simbolik

Selain itu, dapat dilihat bahwa kecenderungan perubahan skor ke arah positive rank. Meskipun demikian, masih terdapat peserta didik yang mengalami penurunan skor (negative) maupun skor yang diperolehnya tetap (ties). Namun, hal tersebut tidak ditinjau lebih lanjut. Pada penelitian ini hasil yang diperoleh lebih ditekankan pada kategorisasi kemampuan peserta didik. Profil perubahan kategori penguasaan konsep peserta didik dapat dilihat pada Gambar 2.

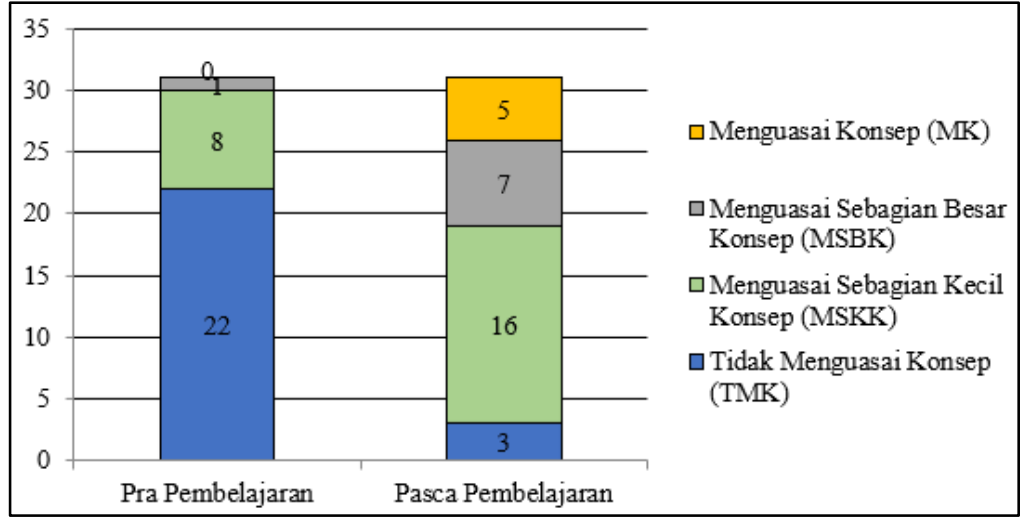

Gambar 2. Profil Perubahan Kategori Penguasaan Konsep Calon Guru Kimia

Dengan melihat Gambar 2, dapat diketahui bahwa porsi TMK pascapembelajaran jauh lebih sedikit jika dibandingkan pra-pembelajaran. Hal ini menunjukkan bahwa ada perbedaan kemampuan yang signifikan. Terlebih lagi, pada pasca-pembelajaran muncul kategori MK, meskipun jumlah peserta didik pada kategori ini paling sedikit dibandingkan kategori lain. Secara lebih rinci pola perubahan kategori peserta didik dapat dilihat pada Gambar 3. 
Formatif: Jurnal Ilmiah Pendidikan MIPA

Vol. 9, No. 3, September 2019, pp. 203-218

p-ISSN: 2088-351X

e-ISSN: 2502-5457

DOI: http://dx.doi.org/10.30998/formatif.v9i3.3248

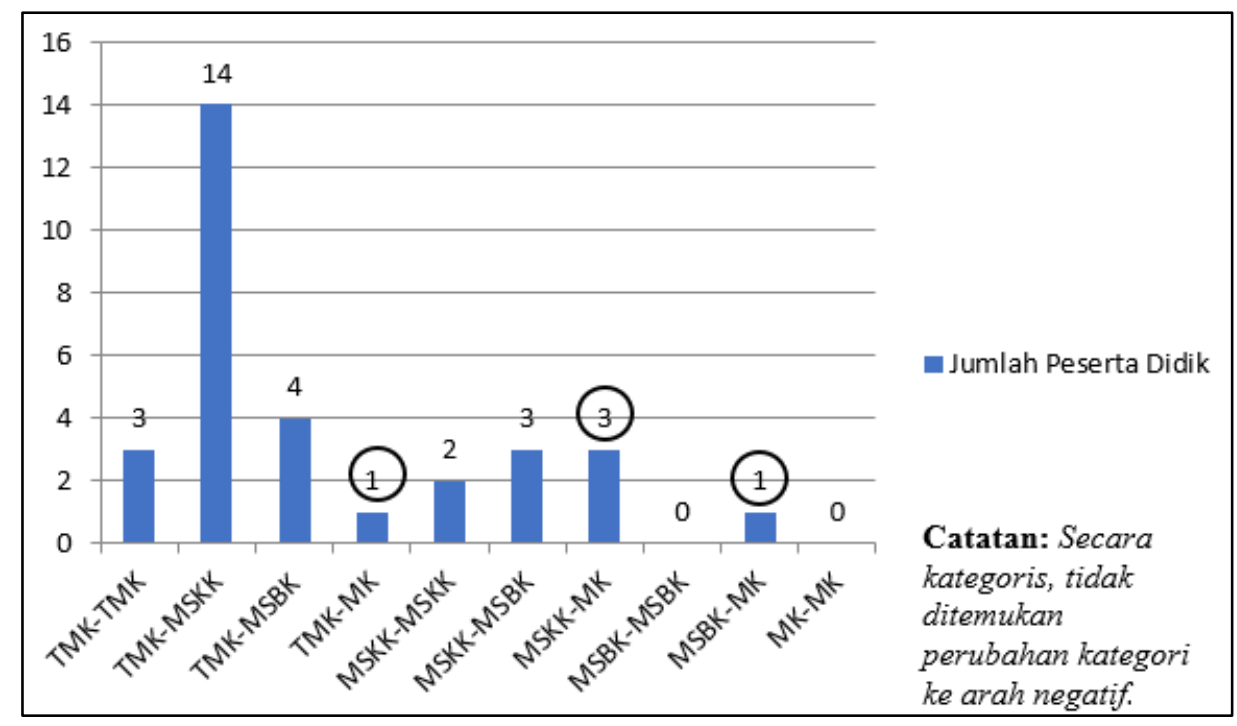

Gambar 3. Profil Pola Perubahan Kategori Penguasaan Konsep Peserta Didik

Berdasarkan pola perubahan kategori Gambar 3, dapat diketahui bahwa peserta didik yang mengalami perubahan kategori TMK menjadi MSKK adalah kelompok peserta didik yang paling banyak. Selain itu, terdapat pula seorang calon guru yang mengalami perubahan kategori dari TMK menjadi MK. Pola tersebut dapat dimengerti dengan meninjau tentang proses pembentukan konsep dan ruang kerja memori (working memory space).

\section{Pembahasan}

Berkaitan dengan pembentukan konsep (concept formation), Sirhan (2007) menyatakan bahwa belajar kimia sebenarnya membutuhkan pemikiran yang intelektual dan kritis karena kontennya penuh dengan konsep abstrak. Hal ini termasuk pula dalam konten materi kimia larutan dan kesetimbangan kimia yang erat dengan penelitian kali ini. Pemahaman nyata (real understanding) tidak hanya membutuhkan pemahaman pada konsep-konsep kunci (key concepts) tetapi juga penyusunan hubungan yang bermakna (meaningful links) untuk membawa konsep saling berhubungan secara keseluruhan. Konsep berkembang sebagai ide-ide baru yang saling berhubungan. Pembelajar, dalam hal ini adalah peserta didik, tidak selalu benar di dalam menghubungkannya. Hal inilah yang mungkin mengarahkan pembentukan miskonsepsi.

Sirhan (2007) lebih lanjut menyatakan bahwa konsep atau potongan pemikiran intelektual yang dimiliki bisa jadi menguatkan atau malah menjadi penghalang (barrier) untuk belajar lebih lanjut. Pola yang demikian dapat dilihat pada Gambar 4 mengenai persebaran derajat pemahaman butir soal secara klasikal. 
Formatif: Jurnal Ilmiah Pendidikan MIPA

Vol. 9, No. 3, September 2019, pp. 203-218

p-ISSN: 2088-351X

e-ISSN: 2502-5457

DOI: http://dx.doi.org/10.30998/formatif.v9i3.3248

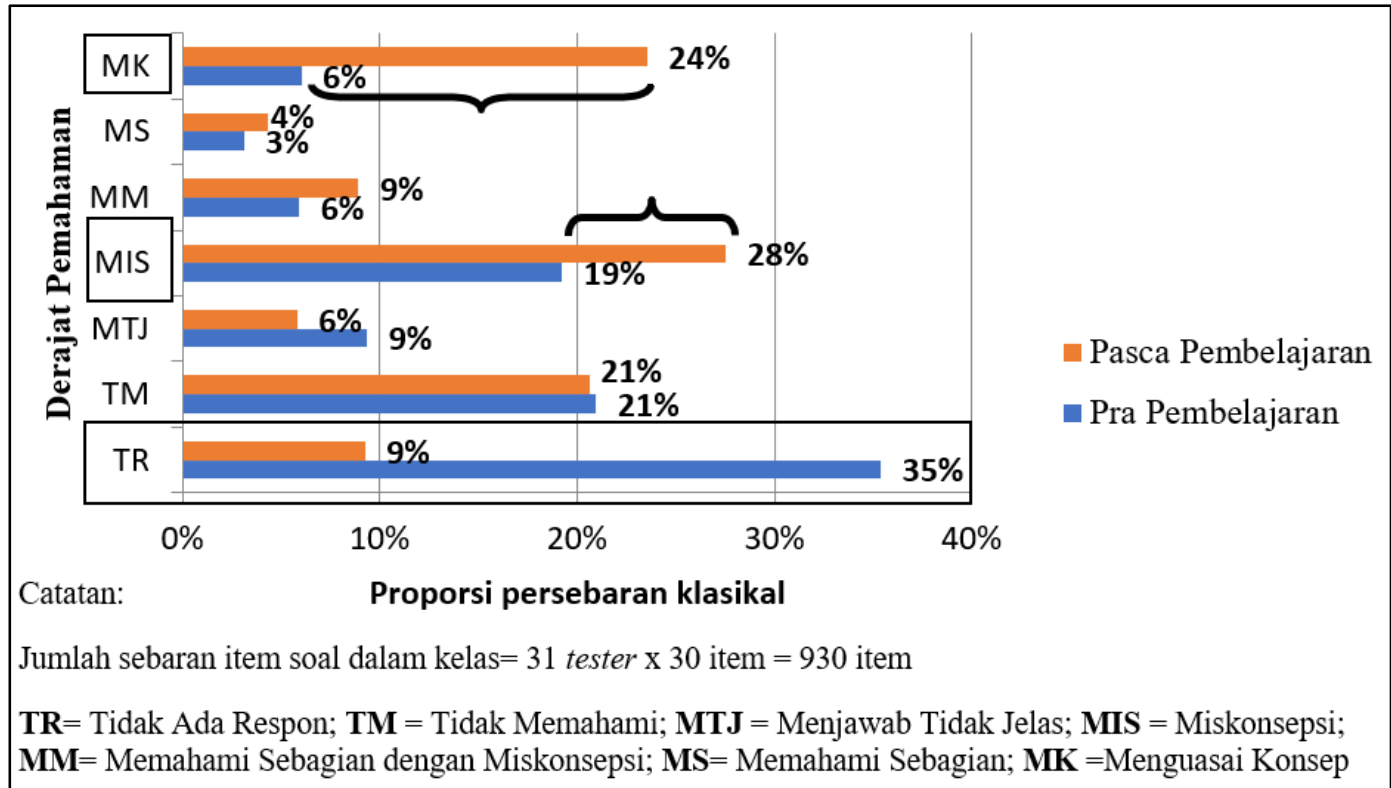

Gambar 4. Profil Persebaran Derajat Pemahaman dalam Butir Soal secara Klasikal

Berdasarkan Gambar 4. derajat TR sangat terlihat perbedaannya setelah pembelajaran. Hal ini karena peserta didik memiliki ide-ide baru dan konsep untuk memberikan respons terhadap item soal setelah pembelajaran. Meskipun demikian, pada proporsi derajat TM hanya mengalami sedikit penurunan. Perubahan proporsi pada derajat MIS dan pada derajat MK merupakan hal yang menarik untuk dikaji. Peningkatan proporsi derajat MK (dari 6\% menjadi 24\%) jauh lebih tinggi dari pada peningkatan proporsi derajat MIS (dari 19\% menjadi 28\%). Dengan demikian, dapat diketahui bahwa pembelajaran berbasis multipel representasi dapat mengarahkan pada penguasaan konsep yang lebih baik meskipun peningkatan proporsi derajat MIS bukanlah hal yang diharapkan.

Untuk melihat perubahan penguasaan konsep lebih lanjut, dilakukan overlay terhadap hasil pre-test dan post-test. Sebelum diadakan overlay, butir-butir soal ditata ulang sehingga butir soal dengan muatan indikator penguasaan konsep yang sama berada pada kode butir yang sama. Dengan demikian, dapat dilihat pola peningkatan yang terjadi. Melalui hasil overlay, dapat dilihat pola perubahan kategori TR, TM, MIS, dan MK pada masing-masing butir soal.

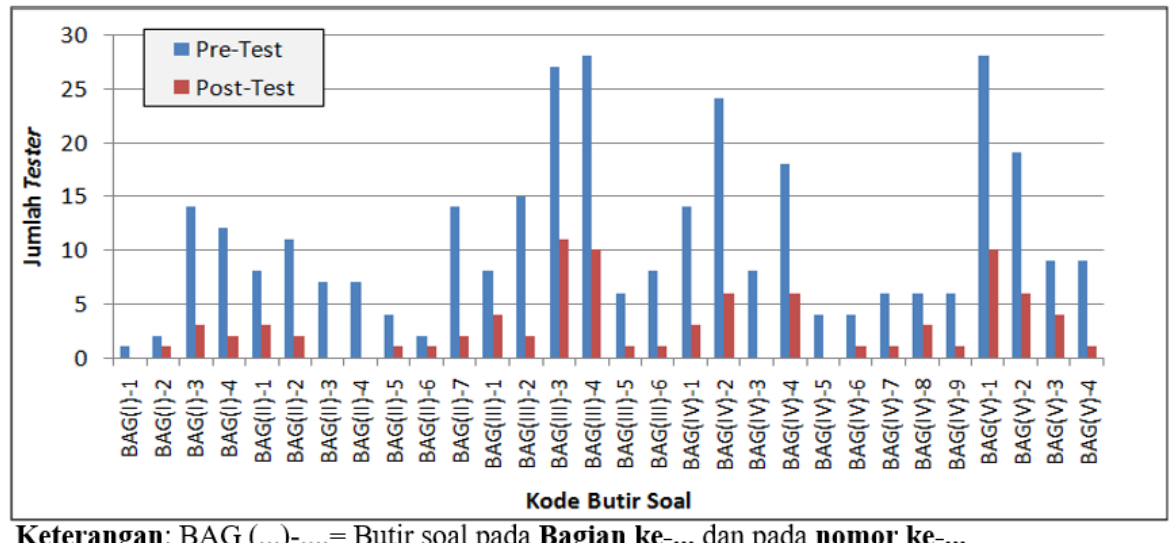

Keterangan: BAG (...)-.... = Butir soal pada Bagian ke-... dan pada nomor ke-

Gambar 5. Pola Perubahan Derajat Penguasaan Konsep TR 
Formatif: Jurnal Ilmiah Pendidikan MIPA

Vol. 9, No. 3, September 2019, pp. 203-218

p-ISSN: 2088-351X

e-ISSN: 2502-5457

DOI: http://dx.doi.org/10.30998/formatif.v9i3.3248

Gambar 5. menunjukkan terjadi pola yang positif dengan melihat jumlah derajat TR yang berkurang pada tiap butir soal. Berbagai respons yang muncul belum bisa dipastikan sebagai respons memahami konsep. Lebih lanjut, dapat diperhatikan pola perubahan respons TM sebagaimana Gambar 6 .

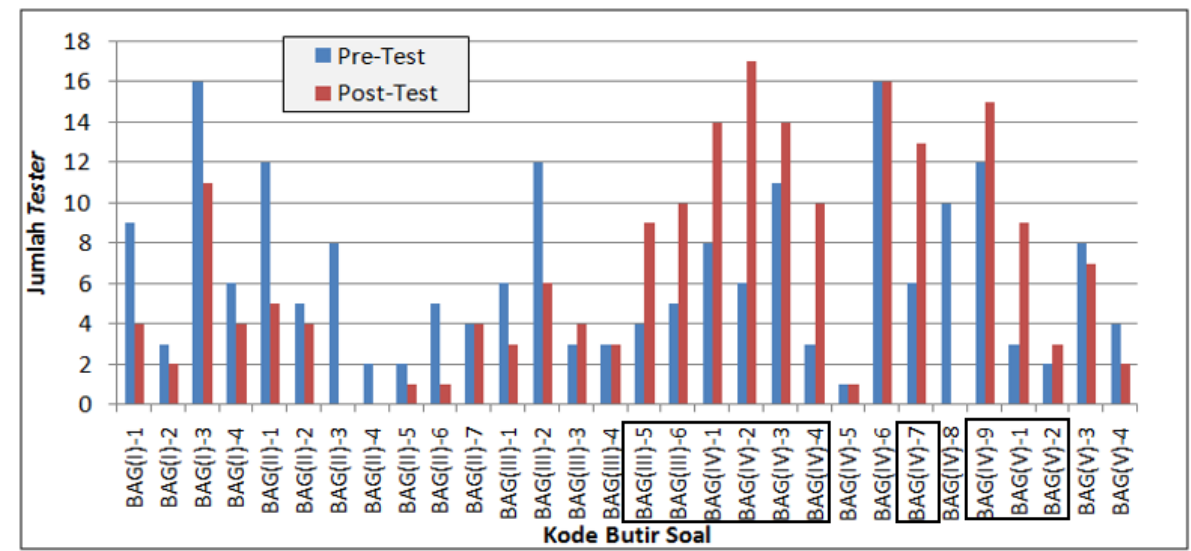

Keterangan: BAG (...)-.... = Butir soal pada Bagian ke-... dan pada nomor ke-... Gambar 6. Pola Perubahan Derajat Penguasaan Konsep TM

Gambar 6 menunjukkan kecenderungan pada kategori TM tiap butir soal mengalami penurunan, meskipun ada beberapa soal dengan jumlah kategori TM meningkat. Hal demikian menunjukkan bahwa beberapa respons yang diberikan pada butir soal muncul sebagai respons tidak memahami konsep. Selanjutnya, penurunan respons tidak memahami (TM) belum bisa dipastikan menjadi respons memahami. Untuk itu, overlay dilakukan pada kategori MIS.

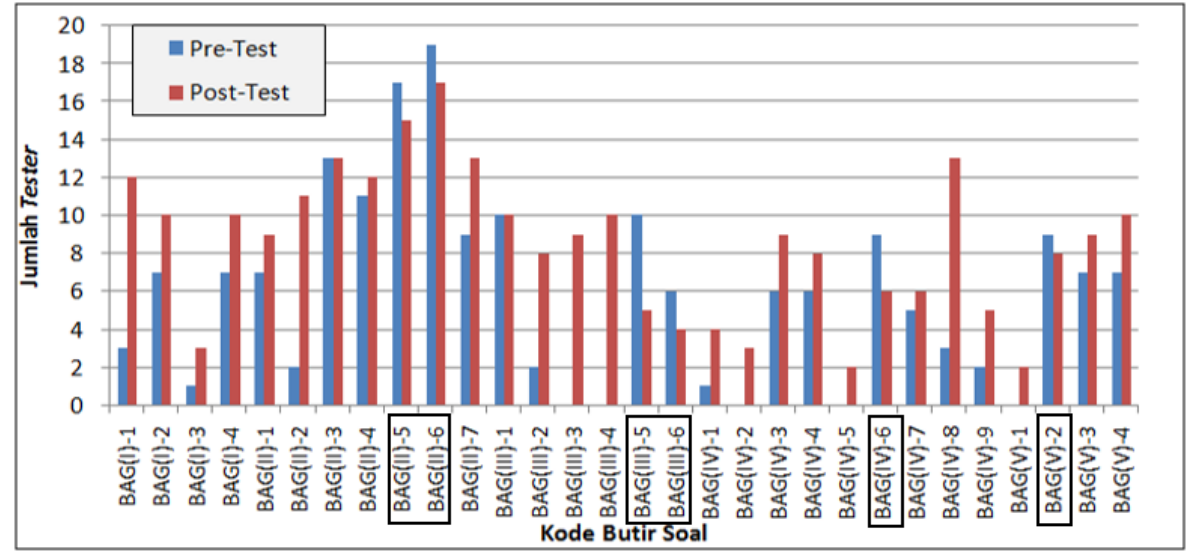

Keterangan: BAG (...)-.... = Butir soal pada Bagian ke-... dan pada nomor ke-...

Gambar 7. Pola Perubahan Derajat Penguasaan Konsep MIS

Derajat pemahaman MIS menunjukkan adanya jawaban yang mengalami miskonsepsi. Berdasarkan Gambar 7, jumlah miskonsepsi yang muncul setelah pembelajaran justru cenderung semakin banyak pada tiap butir soal. Hal ini menunjukkan adanya barrier (penghalang) untuk benar-benar menguasai konsep. Kondisi ini dapat digunakan untuk menjelaskan mengapa gain PK I dan PK IV pada kategori rendah. Kesulitan dalam PK I dapat diindikasikan dari kesulitan peserta didik dalam memahami model gambar submikroskopik. Hal ini sebagaimana diperlihatkan pada Gambar 8 . 
Formatif: Jurnal Ilmiah Pendidikan MIPA

Vol. 9, No. 3, September 2019, pp. 203-218

p-ISSN: 2088-351X

e-ISSN: 2502-5457

DOI: http://dx.doi.org/10.30998/formatif.v9i3.3248

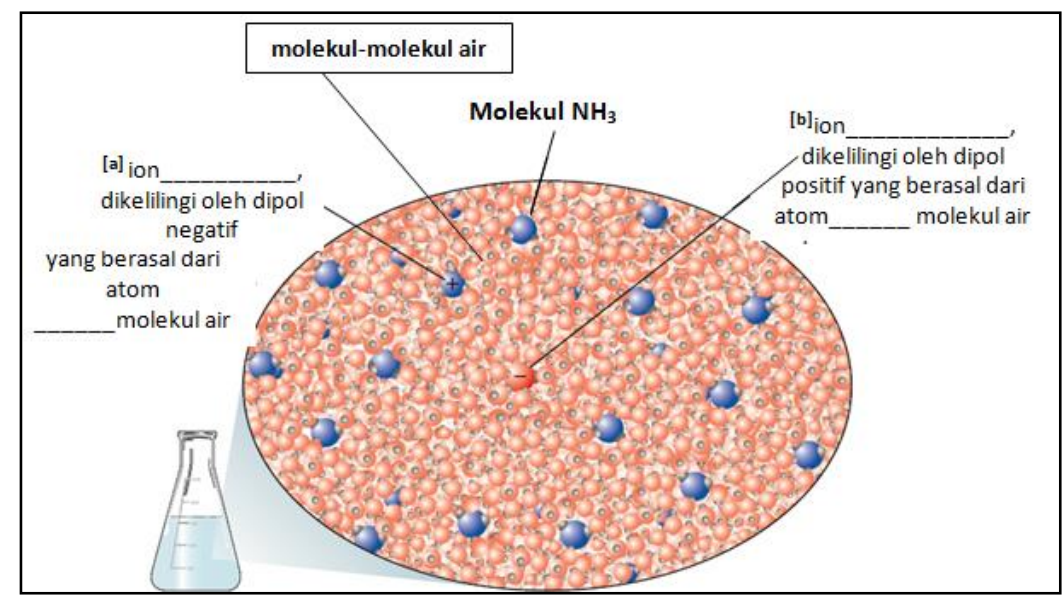

Gambar 8. Cuplikan Gambar Model Submikroskopik pada Soal Post Test (BAG(I)-1).

(menunjukkan pelarutan gas $\mathrm{NH}_{3}$ dalam air).

Barrier atau penghalang yang terjadi pada PK I ini dapat dimengerti karena adanya ketidakmampuan calon guru kimia dalam memahami dan memaknai simbol, rumus, dan gambar model sebelum pembelajaran. Kecenderungan pendidikan yang diperoleh calon guru di sekolah menengah menunjukkan bahwa simbolik kimia berupa persamaan reaksi kimia, indeks fase zat, rumus kimia maupun makna dari formulaformula matematis tidak dimaknai dengan baik. Dengan demikian, calon guru kimia tahun pertama belum menggenggam konsep-konsep kunci ataupun belum benar-benar mampu menghubungkan konsep-konsep kunci.

Bodner (1991) mendata beberapa faktor yang mungkin mengarahkan pada miskonsepsi pada peserta didik. Bodner mencatat masalah-masalah dari pembelajaran yang hanya menekankan pada hafalan, di mana peserta didik memiliki pengetahuan tanpa adanya pemahaman. Sejalan dengan penelitian ini, calon guru tahun pertama belum bisa benar-benar memahami atom, molekul, ion, rumus kimia, serta representasi simbolik dan submikroskopik yang berhubungan dengan materi asam basa dan kesetimbangan kelarutan. Hal inilah yang mungkin pula menjadi faktor kunci adanya miskonsepsi.

Indikator PK I menuntut calon guru untuk memahami deskripsi asam-basa lemah dan kuat secara submikroskopik dan simbolik. Kajian Ben-Zvi, Eylon, dan Silberstein's (1988) yang dipaparkan oleh Wu et al. (2001) menyelidiki level deskripsi peserta didik ketika rumus-rumus dan simbol-simbol kimia digunakan, seperti $\mathrm{Cu}(\mathrm{s}), \mathrm{H}_{2} \mathrm{O}(\mathrm{l})$, dan $\mathrm{Cl}_{2}(\mathrm{~g})$. Respons peserta didik menunjukkan bahwa mayoritas dari mereka masih kebingungan antara atom dan molekul. Konsep model mikroskopik atom dan molekul begitu problematik. Sejalan dengan temuan Ben-Zvi, Eylon, dan Silberstein's, penelitian ini juga memperlihatkan kondisi yang selaras. Penggunaan simbol indeks (s), (l), (g) dan (aq) untuk menunjukkan fase dari zat juga belum bisa dipahami dan dipergunakan dengan baik oleh calon guru sebelum ataupun setelah pembelajaran. Hal yang demikian juga sejalan dengan penyelidikan Ben-Zvi et.al bahwa banyak peserta didik, bahkan setelah belajar kimia, masih tidak mengerti peran rumus kimia. Beberapa berpikir bahwa rumus kimia hanyalah singkatan untuk mewakili komposisi atau struktur.

Berkaitan dengan cara berpikir tersebut, pada penelitian ini ditemukan bahwa calon guru sering mengalami kesalahan dalam mengidentifikasi sifat $\mathrm{HNO}_{2}$ sebagai asam lemah. Sebagai contoh, banyak ditemukan bahwa $\mathrm{HNO}_{2}$ dianggap sebagai asam kuat, dan sering dituliskan sebagai $\mathrm{HNO}_{3}$. Mayoritas calon guru belum menyadari bahwa secara karakteristik $\mathrm{HNO}_{2}$ berbeda dengan $\mathrm{HNO}_{3}$. Lebih lanjut, mayoritas calon guru belum bisa menuliskan mekanisme persamaan reaksi hidrolisis. Mereka belum bisa menunjukkan 
Formatif: Jurnal Ilmiah Pendidikan MIPA

Vol. 9, No. 3, September 2019, pp. 203-218

p-ISSN: 2088-351X

e-ISSN: 2502-5457

DOI: http://dx.doi.org/10.30998/formatif.v9i3.3248

bahwa komponen $\mathrm{NO}_{2}^{-}$(pada $\mathrm{NaNO}_{2}$ ) mengalami hidrolisis dan membentuk ion $\mathrm{OH}^{-}$ sehingga garam yang terhidrolisis bersifat basa. Pada jawaban TPKL terkait dengan PK IV, jika kita tinjau dari pola TM dan MIS, pola yang terjadi adalah peningkatan.

Sebenarnya ketika pendidik (guru) memperkenalkan sebuah gagasan -semisal rumus-rumus senyawa kimia, persamaan reaksi, dan sebagainya-, pembelajar (peserta didik) mungkin sudah memiliki pengetahuan atau pengalaman sebelumnya sehingga mengarah pada kebingungan (Sirhan, 2007). Hal lain yang dapat disoroti adalah kemampuan calon guru untuk memaknai kurva titrasi. Mereka belum bisa memaknai adanya konsep sistem penyangga dan hidrolisis pada kurva. Untuk memenuhi indikatorindikator penguasaan konsep yang ada, calon guru tentunya harus memaknai setiap simbol, rumus, representasi berupa gambar, grafik, dan kurva.

Berdasarkan uraian di atas, dapat diketahui bahwa banyak respons yang berubah dari tidak ada respons (TR) menjadi miskonsepsi (MIS). Meskipun demikian, respons positif juga dapat terlihat pada perubahan pola respons menguasai konsep (MK) seperti yang diperlihatkan pada Gambar 7.

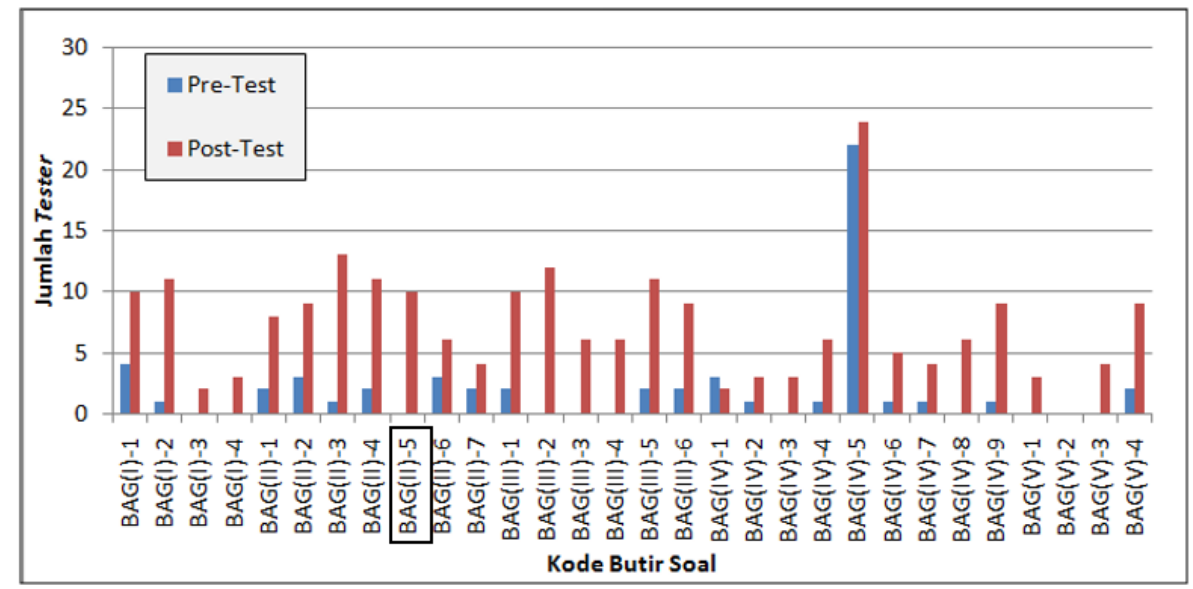

Keterangan: BAG (...)-.... = Butir soal pada Bagian ke-... dan pada nomor ke-...

Gambar 7. Pola Perubahan Derajat Penguasaan Konsep MK

Gambar 7 memperlihatkan peningkatan pada level MK tiap butir soal. Jika diperhatikan dengan seksama pada perubahan pola yang terjadi, maka dapat diketahui bahwa secara level submikroskopik, telah terjadi pula perubahan konsep ke arah yang lebih baik. Contoh konkret pada BAG(II)-5, dapat diketahui bahwa derajat TR terjadi penurunan, TM terjadi penurunan, MIS terjadi penurunan, dan MK dari mulanya tidak muncul sama sekali sehingga pada pasca-pembelajaran muncul kategori MK.

BAG(II)-5 menanyakan "Apakah di dalam larutan asam semisal: $\mathrm{HCl}$ 0,0001 M (berpelarut air) terdapat ion OH- atau tidak?". Berdasarkan jawaban dari mayoritas calon guru, dapat diketahui bahwa terdapat perubahan pemahaman secara submikroskopik dan simbolik. Mayoritas peserta didik sudah mampu mempertimbangkan keberadaan air di dalam larutan dan menuliskan reaksi autoionisasi dengan tepat. Calon guru sudah mampu untuk membayangkan secara submikroskopik, serta menuliskan dan menunjukkan keberadaan ion $\mathrm{OH}$ - secara simbolik.

Santrock (2011)menyatakan bahwa seseorang mempunyai banyak miskonsepsi yang tidak kompatibel dengan sains dan realitas. Berkaitan dengan hal tersebut, penggunaan bahasa ilmiah (scientific language) juga bisa mengarah pada miskonsepsi yang menyesatkan. Sebagai contoh, "atom" mungkin saja langsung dianalogikan oleh peserta didik seperti "kacang atom" di mana terdapat inti dan kulit atom. Akan tetapi, 
Formatif: Jurnal Ilmiah Pendidikan MIPA

Vol. 9, No. 3, September 2019, pp. 203-218

p-ISSN: 2088-351X

e-ISSN: 2502-5457

DOI: http://dx.doi.org/10.30998/formatif.v9i3.3248

peserta didik belum bisa dengan mudah mengimajinasikan bentuk atom di mana terdapat "orbital atom" dan kondisi "melepas dan menerima elektron". Hal ini bisa jadi menyusahkan pendidik ketika menjelaskan tentang "ion" yang berhubungan dengan kondisi "melepas dan menerima elektron". Johnston menyatakan bahwa bahasa dapat menjadi salah satu kontributor dalam overload informasi (Sirhan, 2007). Permasalahan bahasa termasuk pada penggunaan kosakata yang tidak familier (contoh: ion, molekul, katalis), kosakata familier yang mengarah pada pergeseran makna ke arah kimia (contoh: atom, jenuh), penggunaan bahasa yang terdengar tingkat tinggi (contoh: entitas), dan penggunaan dobel atau tripel makna negatif. Contoh yang menarik berkaitan dengan pengaruh bahasa pada ruang kerja memori adalah penelitian tentang penggunaan second language pada anak sekolah menengah. Hasil menunjukkan adanya penurunan sekitar satu unit pada ruang kerja memori. Johnstone \& Selepeng (2001) menyatakan bahwa unit memori kerja digunakan untuk mengatur transfer bahasa. Sejalan dengan hal tersebut, Gardner (1972) melakukan penelitian tentang keterampilan kosakata pada peserta didik sekolah menengah di Australia. Hasil menunjukkan bahwa banyak kata-kata yang digunakan oleh guru sains tidak dapat diakses dan dimengerti oleh peserta didik. Penelitian di Skotlandia juga menunjukkan bahwa beberapa kata -yang penggunaannya tidak standar dalam bahasa Inggris- menyebabkan ketidakpahaman peserta didik. Penggunaan bahasa, termasuk representasi simbol-simbol, membutuhkan pemikiran yang cermat dan kehati-hatian. Bahasa dapat membantu ataupun menghalangi interaksi dengan memori jangka panjang (long-term memory) bahkan juga bisa menjadi sumber dari kelebihan (overload) memori kerja informasi (Sirhan, 2007; Taber, 2009). Pada penelitian ini terdapat indikasi bahwa calon guru kesulitan pada pemrosesan informasi dan hal ini berhubungan dengan penggunaan bahasa dalam mengaitkan level-level representasi kimia.

Pembelajaran berbasis multipel level representasi yang telah dilaksanakan pada dasarnya berhubungan dengan sensor memori penglihatan dan pendengaran. Penglihatan terkait dengan teks dan gambar yang ada di dalam lembar kerja, serta animasi yang mungkin ditampilkan pada media visual lainnya. Adapun pendengaran terkait dengan pemaparan dan kegiatan diskusi. Keduanya ini berinteraksi di dalam ruang kerja memori. Selain itu, pengetahuan pada memori jangka panjang juga saling berinteraksi dalam ruang kerja memori. Miskonsepsi akan bisa terjadi jika tidak terjadi integrasi yang baik di antara semua komponen.

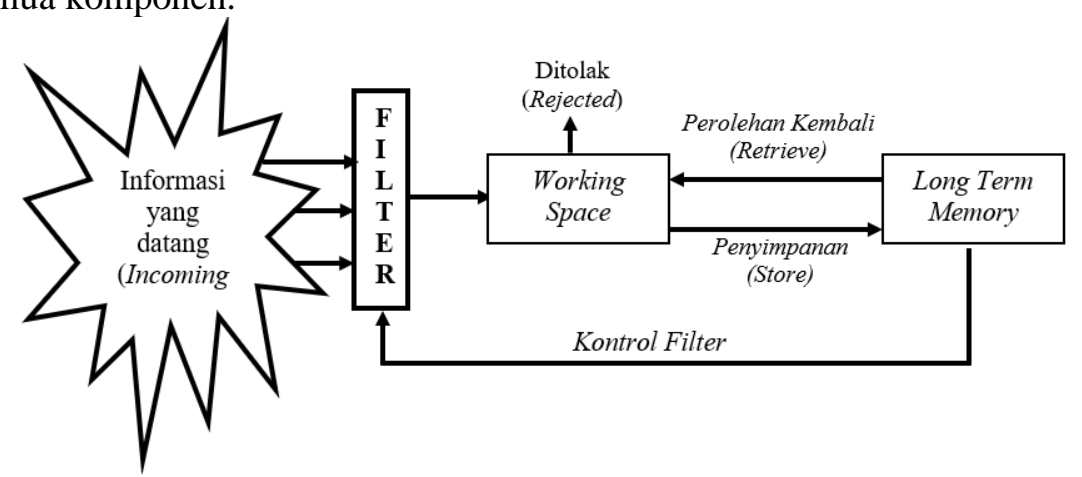

Gambar 8. Model Pemrosesan Informasi

Johnstone \& Selepeng (2001) menggambarkan model pemrosesan informasi seperti yang dimodifikasi pada Gambar 8. Informasi yang berhasil lolos melalui filter akan menuju working space (atau working memory), yaitu bagian dari ingatan (mind) di mana informasi-informasi baru berinteraksi dengan apa yang sudah dipahami dan sudah dimengerti. Informasi-informasi tersebut dibentuk menjadi bentuk yang dapat disimpan 
Formatif: Jurnal Ilmiah Pendidikan MIPA

Vol. 9, No. 3, September 2019, pp. 203-218

p-ISSN: 2088-351X

e-ISSN: 2502-5457

DOI: http://dx.doi.org/10.30998/formatif.v9i3.3248

dan digunakan kembali nantinya ataupun ke dalam bentuk yang dapat dibuang karena dianggap sebagai hal yang "tidak berarti". Dengan memahami model-model pemrosesan informasi, setidaknya terdapat faktor penting untuk menjelaskan mengapa sains (dalam hal ini kimia) menjadi sulit bagi peserta didik. Hal tersebut dikarenakan bahasa dalam kimia membutuhkan proses yang terlalu berlebihan. Bahasa di sini juga termasuk penggunaan representasi simbol-simbol (Bradley \& Steenberg, 2005; Chao, 1968; Osborne, 2002; Sirhan, 2007; Taber, 2009; Wellington \& Osborne, 2001).

Taber (2009) menyatakan lebih lanjut bahwa berbagai representasi simbolik yang digunakan dalam kimia merupakan bagian dari bahasa khusus (specialist language) yang dinamakan The Lingua-Chemica. Representasi simbolik ini terintegrasi dengan pemahaman konseptual (conceptual understanding) dan pengetahuan subjek (subject knowledge). Sirhan (2007) menunjukkan hubungan antara pemahaman konseptual (conceptual understanding), konten informasi (information cotent), dan kesulitan (difficulty). Peserta didik yang memiliki pemahaman konseptual rendah mampu menunjukkan performance pada kondisi muatan informasi yang sedikit (low information load), tetapi performance-nya akan menurun jika muatan informasi semakin meningkat. Hal tersebutlah yang menyebabkan perasaan sulit (difficulty perceived). Kaitannya dengan hal tersebut, Johnstone (dalam Sirhan, 2007) menggambarkan Diagram "Concorde" pada Gambar 9.

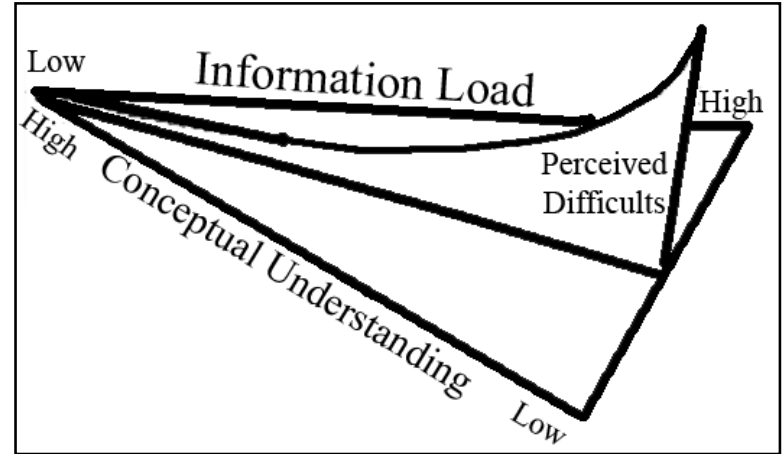

Gambar 9. Diagram "Concorde" dari Johnstone.

Sumber: Sirhan (2007)

Gambar 9 menunjukkan jika pembelajar (learner) dengan kemampuan konseptual rendah berada pada kondisi dengan muatan informasi (information load) yang meningkat (high), maka barrier atau penghalang yang berupa perasaan sulit (perceived difficulty) juga meningkat dan begitu pula sebaliknya. Jika pendidik memberikan informasi dengan muatan yang berlebih padahal hal tersebut merupakan hal yang baru bagi peserta didik, yang terjadi adalah barrier perasaan sulit akan meningkat. Taber (2009) menyatakan bahwa kesulitan dalam mempelajari ide-ide kimia akan muncul jika tidak memahami seluk beluk bahasa simbolik. Ketidakpahaman secara mendalam ini akan mudah membuat kesalahpahaman (misinterpretasi) apa yang direpresentasikan melalui bahasa. Dengan demikian, jika perasaan sulit tersebut menurun hal tersebut menjadi salah satu indikasi bahwa pemahaman peserta didik akan seluk beluk bahasa simbolik semakin meningkat.

Berdasarkan hal tersebut, pada penelitian ini dapat diketahui bahwa muatan yang disajikan pada pembelajaran berbasis multipel level representasi mampu untuk menurunkan barrier perasaan sulit yang dimiliki peserta didik. Hal tersebut dapat dilihat dari hasil penilaian diri peserta didik terhadap kemampuannya dalam menghubungkan level representasi kimia (pada Gambar 1.). Jika dilihat kembali pada profil penilaian diri tersebut, dapat diketahui bahwa terjadi perubahan respons ke arah positif. Respons 
Formatif: Jurnal Ilmiah Pendidikan MIPA

Vol. 9, No. 3, September 2019, pp. 203-218

p-ISSN: 2088-351X

e-ISSN: 2502-5457

DOI: http://dx.doi.org/10.30998/formatif.v9i3.3248

tersebut mengindikasikan penurunan barrier perasaan sulit. Yuliyani, Handayani, \& Somawati (2017) menunjukkan bahwa terdapat pengaruh langsung yang signifikan kemampuan berpikir positif terhadap kemampuan pemecahan masalah. Dengan menurunnya Barrier tersebut maka terdapat indikasi bahwa penguasaan konsep calon guru meningkat. Transisi penguasaan konsep calon guru menuju ke arah yang lebih baik setelah mengalami pembelajaran berbasis multipel representasi.

\section{PENUTUP}

Hasil penelitian ini menunjukkan transisi penguasaan konsep calon guru kimia tentang larutan pada pembelajaran berbasis multipel representasi. Transisi penguasaan konsep calon guru menuju ke arah yang lebih baik setelah mengalami pembelajaran berbasis multipel representasi. Gain penguasaan konsep yang diperoleh pada level sedang $(0,30)$. Penguasaan konsep I (yaitu membandingkan teori asam-basa menurut teori Arrhenius, Bronsted- Lowry, dan Lewis pada level makroskopik, submikroskopik, dan simbolik) dan penguasaan konsep IV (yaitu menunjukkan hubungan konsep hidrolisis dalam larutan dan penentuan $\mathrm{pH}$ larutan pada level makroskopik, submikroskopik, dan simbolik) lebih sedikit peningkatan penguasaannya dibandingkan konsep-konsep yang lain. Calon guru yang mengalami perubahan kategori TMK menjadi MSKK adalah kelompok peserta didik yang paling banyak. Selain itu, terdapat pula seorang peserta didik yang mengalami perubahan kategori dari TMK menjadi MK.

Pola tersebut dapat dimengerti dengan meninjau tentang proses pembentukan konsep dan ruang kerja memori. Konten yang disajikan pembelajaran mampu untuk menurunkan barrier perasaan sulit yang dimiliki calon guru. Penurunan barrier tersebut mengindikasikan bahwa penguasaan konsep calon guru meningkat dengan adanya pembelajaran berbasis multipel level representasi. Penelitian lebih lanjut perlu diarahkan pada perbaikan proses pembelajaran berbasis multipel representasi serta pengembangan pada konten konsep kimia lainnya yang masih diindikasikan memiliki banyak miskonsepsi terutama pada konten yang memerlukan penguasaan khusus pada level simbolik dan submikroskopik.

\section{DAFTAR PUSTAKA}

Abraham, M. R., Grzybowski, E. B., Renner, J. W., \& Marek, E. A. (1992). Understandings and misunderstandings of eighth graders of five chemistry concepts found in textbooks. Journal of Research in Science Teaching, 29(2), 105-120. https://doi.org/10.1002/tea.3660290203

Bodner, G. M. (1991). I have found you an argument: The conceptual knowledge of beginning chemistry graduate students. Journal of Chemical Education, 68(5), 385. https://doi.org/10.1021/ed068p385

Bradley, J. D., \& Steenberg, E. (2005). Symbolic Language In Chemistry - A New Look At An Old Problem. Pretoria: University of South Africa (UNISA). Retrieved from https://old.iupac.org/publications/cei/vol8/0801xSteenberg.pdf

Chandrasegaran, A. L., Treagust, D. F., \& Mocerino, M. (2007). The development of a two-tier multiple-choice diagnostic instrument for evaluating secondary school students' ability to describe and explain chemical reactions using multiple levels of representation. Chem. Educ. Res. Pract., 8(3), 293-307. https://doi.org/10.1039/B7RP90006F 
Formatif: Jurnal Ilmiah Pendidikan MIPA

Vol. 9, No. 3, September 2019, pp. 203-218

p-ISSN: 2088-351X

e-ISSN: 2502-5457

DOI: http://dx.doi.org/10.30998/formatif.v9i3.3248

Chao, Y. R. (1968). Language And Symbolic Systems. California: Cambridge At The University Press.

Chittleborough, G., \& Treagust, D. F. (2007). The modelling ability of non-major chemistry students and their understanding of the sub-microscopic level. Chem. Educ. Res. Pract., 8(3), 274-292. https://doi.org/10.1039/B6RP90035F

Cohen, L., Manion, L., \& Morrison, K. (2007). Research Methods in Education (Sixth Edit). . New York: Routledge.

Devetak, I., Urbančič, M., K.S.W., G., Krnel, D., \& Glažar, S. A. (2004). Submicroscopic representations as a tool for evaluating students' chemical conceptions. Acta Chim Slov, 51, 799-814.

Devetak, I., Vogrinc, J., \& Glažar, S. A. (2009). Assessing 16-year-old students' understanding of aqueous solution at submicroscopic level. Research in Science Education, 39(2), 157-179. https://doi.org/10.1007/s11165-007-9077-2

Farida, I. (2012). Interkoneksi Multipel Level Representasi Mahasiswa Calon Guru pada Kesetimbangan dalam Larutan melalui Pembelajaran Berbasis Web. Universitas Pendidikan Indonesia.

Gardner, P. L. (1972). Words in Science. Melbourne.

Hake, R. R. (1998). Interactive-engagement versus traditional methods: A six-thousandstudent survey of mechanics test data for introductory physics courses. American Journal of Physics, 66(1), 64-74. https://doi.org/10.1119/1.18809

Hinton, M. E., \& Nakhleh, M. B. (1999). Students? Microscopic, macroscopic, and symbolic representations of chemical reactions. The Chemical Educator, 4(5), 158167. https://doi.org/10.1007/s00897990325a

Imaduddin, M. (2018). Analisis miskonsepsi submikroskopik konsep larutan pada calon guru kimia. Edu Sains: Jurnal Pendidikan Sains \& Matematika, 6(2), 1. https://doi.org/10.23971/eds.v6i2.983

Johnstone, A. H. (2000). Chemical education research: Where from here? Proceeding University Chemistry Education, 4(1), 34-38. Retrieved from https://www.physics.utoronto.ca/ key/PHY1600/PER Papers/Chemical Education Research.pdf

Johnstone, A. H. (2000). Teaching of chemistry - logical or psychological? Chem. Educ. Res. Pract., 1(1), 9-15. https://doi.org/10.1039/A9RP90001B

Johnstone, A. H., \& Selepeng, D. (2001). A Language Problem Revisited. Chem. Educ. Res. Pract., 2(1), 19-29. https://doi.org/10.1039/B0RP90028A

Karnoto, K., \& Wibisono, Y. (2004). Petunjuk Instalasi dan Pengoperasian ANATES Versi 4. Bandung: Universitas Pendidikan Indonesia.

Muchtar, Z. \& Harizal, H. (2012). Analyzing of students' misconceptions on acid-base chemistry at senior high schools in Medan. Journal of Education and Practice, $3(15), 65-74$.

Osborne, J. (2002). Science without literacy: A ship without a sail? Cambridge Journal of Education, 32(2), 203-218. https://doi.org/10.1080/03057640220147559

Santrock, J. W. (2011). Educational Psychology (Fifth edit). New York: McGraw-Hil.

Schmidt, H., \& Chemie, F. (1995). Applying the concept of conjugation to the BrØnsted theory of acid-base reactions by senior high school students from Germany. International Journal of Science Education, 17(6), 733-741. https://doi.org/10.1080/0950069950170605

Sirhan, G. (2007). Learning difficulties in chemistry: An overview. Journal of Turkish Science Education, 4(2), 1-20.

Sukardi, S. (2009). Evaluasi Pendidikan Prinsip \& Operasionalnya. Jakarta: PT Bumi Aksara. 
Formatif: Jurnal Ilmiah Pendidikan MIPA

Vol. 9, No. 3, September 2019, pp. 203-218

p-ISSN: 2088-351X

e-ISSN: 2502-5457

DOI: http://dx.doi.org/10.30998/formatif.v9i3.3248

Taber, K. S. (2009). Learning at the Symbolic Level. In J. Gilbert \& D. F. Treagust (Eds.), Multiple Representation in Chemical Education: Models \& Modelling in Science Education (pp. 75-105). Dordrecht: Springer.

Talanquer, V. (2011). Macro, submicro, and symbolic: The many faces of the chemistry "triplet". International Journal of Science Education, 33(2), 179-195. https://doi.org/10.1080/09500690903386435

Tasker, R., \& Dalton, R. (2006). Research into practice: visualisation of the molecular world using animations. Chemistry Education Research and Practice, 7(2), 141159. https://doi.org/10.1039/B5RP90020D

Treagust, D. F., \& Chandrasegaran, C. (2009). The Efficacy of An Alternative Instructional Programme Designed to Enhance Secondary Students' Competence in The Triplet Relatioship. In J. Gilbert \& D. Treagust (Eds.), Multiple Representation in Chemical Education: Models \& Modelling in Science Education (pp. 151-164). Dordrecht: Springer.

Tuysuz, M., Ekiz, B., Uzuntiryaki, E., Tarkin, A., \& Kutucu, E. S. (2011). Pre-service chemistry teachers' understanding of phase changes and dissolution at macroscopic, symbolic, and microscopic levels. Procedia Social and Behavioral Sciences Elsevier, 15, 452-455. https://doi.org/https://doi.org/10.1016/j.sbspro.2011.03.120

Wellington, J., \& Osborne, J. (2001). Language and Literacy In Science Education. Philadelphia: Open University Press.

Wu, H.-K., Krajcik, J. S., \& Soloway, E. (2001). Promoting understanding of chemical representations: Students' use of a visualization tool in the classroom. Journal of Research in Science Teaching, 38(7), 821-842. https://doi.org/10.1002/tea.1033

Yuliyani, R., Handayani, S. D., \& Somawati, S. (2017). Peran efikasi diri (self-efficacy) dan kemampuan berpikir positif terhadap kemampuan pemecahan masalah matematika. Formatif: Jurnal Ilmiah Pendidikan MIPA, 7(2), 130-143. https://doi.org/10.30998/formatif.v7i2.2228 